\title{
Evaluation of biochemical treatments applied in polluted soils irrigated with low quality water for long periods of time through the $\mathrm{CO}_{2}$ efflux
}

\author{
Mohamed SABER ${ }^{1}$, Alaa ZAGHLOUL ${ }^{2,3}$
}

Received February 21, 2021; accepted November 26, 2021. Delo je prispelo 21. februarja 2021, sprejeto 26. novembra 2021

Evaluation of biochemical treatments applied in polluted soils irrigated with low quality water for long periods of time through the $\mathrm{CO}_{2}$ efflux

Abstract: To sightsee the bearings of the certain remediation amendments, usually applied in the bioremediation of soils irrigated with low quality water for extended periods on the indigenous microbial population, a greenhouse experiment was conducted at National Research Centre (NRC) where the soil ecosystem was supplied with varied mineral remediation amendments and the carbon dioxide $\left(\mathrm{CO}_{2}\right)$ refluxes were followed up. In this study, microbial activity through $\mathrm{CO}_{2}$ efflux was taken as an indicator to evaluate the effectiveness of eight soil amendments in minimizing the hazards of inorganic pollutants in soil ecosystem irrigated with low quality water $s$ for more than 40 years. Results showed that $\mathrm{Ni}$ and $\mathrm{Zn}$ were the most dominant contaminants that adversely influenced indigenous microbial activities in untreated soil, while $\mathrm{Cu}$ was the most persuasive. All trailed remediation amendments significantly minimized the hazards of inorganic pollutants in treated soil ecosystems. In addition, modified bentonite (Probentonite) was the best persuasive one. Mechanisms take place between trailed remediation amendments and inorganic pollutants in the studied soil ecosystems were discussed. In conclusion application of certain raw or modified clay minerals especially Probentonite could be a good tool in decreasing the rate of the studied inorganic pollutants in a contaminated soil ecosystem irrigated with low quality water for extended periods.

Key words: soil; low quality water; bioremediation; potential toxic elements; soil indigenous microbial Activities; modified clay minerals
Ovrednotenje biokemičnih obravnavanj onesnaženih tal, ki so bila dalj časa namakana $\mathrm{z}$ vodo slabe kakovosti $\mathrm{z}$ meritvijo sproščanja $\mathrm{CO}_{2}$

Izvleček: Za prepoznavanje obremenitev, ki jih povzročajo nekateri remediacijski dodatki, ki se navadno uporabljajo pri bioremediaciji tal namakanih dalj časa $\mathrm{z}$ vodo slabe kakovosti na samoniklo mikrobno populacijo, je bil izveden poskus v rastlinjaku v nacionalnem raziskovalnem centru (NRC). Tlem so dodajali različne mineralne remediacijske dodatke in spremljali sproščanje ogljikovega dioksida $\left(\mathrm{CO}_{2}\right)$. Mikrobna aktivnost, izražena kot iztok $\mathrm{CO}_{2}$, je služila kot indikator ovrednotenja učinkovitosti osmih talnih dodatkov, ki naj bi zmanjšali škodo, ki jo $\mathrm{v}$ talnem ekosistemu povzročajo anorganska onesnaževala iz vode za namakanje slabe kakovosti v obdobju več kot 40 let. Rezultati so pokazali, da sta bila Ni in Zn dominantna kontaminanta, ki sta negativno vplivala na aktivnost samoniklih mikrobov v obravnavanih tleh medtem, ko je bil učinek $\mathrm{Cu}$ največji. Vsi poskusi dodatkov $\mathrm{v}$ remediaciji so značilno zmanjšali tveganja poškodbe tal zaradi anorganskih polutantov v obravnavanih talnih ekosistemih. Pri tem je bil spremenjeni bentonit (Probentonite) najučinkovitejši. V raziskavi so interpretirani mehanizmi, ki potekajo med dodatki v remediaciji in anorganskimi onesnaževali $\mathrm{v}$ preučevanih talnih ekosistemih. Zaključek je, da je dodatek nekaterih osnovnih ali spremenjenih glinenih mineralov, še posebej probentonita lahko dobro sredstvo za zmanševanje onesnaženja z nekaterimi anorganskimi onesnaževali v onesnaženih ekosistemih, ki so bili namakani $\mathrm{z}$ vodo slabe kakovosti v daljšem obdobju.

Ključne besede: tla; voda slabe kakovosti; bioremediacija; potencialno toksični elementi; aktivnost samoniklih talnih mikrobov; spremenjeni glineni minerali

1 Department of Agricultural Soil Microbiology, National Research Centre, Dokki, Cairo, Egypt

2 Soils and Water Use Department, National Research Centre, Dokki, Cairo, Egypt

3 Corresponding author, e-mail: alaazaghloul2008@gmail.com 


\section{INTRODUCTION}

Through low quality water farming varied organic and inorganic contaminates reach the soil together with enteric pathogens, and cause vital adverse agricultural, environmental and public health troubles. Biological pollutants include bacteria, viruses, and parasites that are responsible for waterborne diseases, such as typhoid fever, cholera, dysentery, polio, hepatitis, and schistosomiasis. The presence of coliform bacteria is indicator of recent fecal pollution, this type of contamination is exclusively attributed to human and animal waste. Also, in these materials inorganic pollutants include cations and anions, most of them naturally occurring in soils, sediments, and rocks. Cations include heavy metals, such as cadmium $(\mathrm{Cd})$, chromium $(\mathrm{Cr} \mathrm{VI})$, lead $(\mathrm{Pb})$, manganese $(\mathrm{Mn})$, mercury $(\mathrm{Hg})$, and nickel (Ni). These highly toxic chemicals may reach soil after mineral dissolution with low quality waters applied or from industrial activities or after industrial emissions (Saber et al., 2015).Although low quality water farming was always associated with potential benefits as well as with problems, yet appropriate practices to ensure its safe and effective sustainable use are not well developed (Doaa Ali et al, 2020). The role of microorganism on the health of soil ecosystem is incontestable. Since 1930 huge amounts of agrochemicals were applied to soil ecosystems and adversely impacted their biome activities, Khan and Scullion (2000) recorded a shift in bacterial to fungal population in soil ecosystems as a result of contamination with inorganic pollutants. Recently, one of the narrative concepts of soil health is bioremediation of contaminated soil ecosystems using varied remediation amendments, some of which with negative impacts on soil microbial activities (Kelly and Tate III, 1998). It is worthy to state that the influence of the inorganic pollutants on the respiration intensity in a soil ecosystem irrigated with low quality water for extended periods was somewhat inconsistent, Yonebayashi and Hattori (1989) and Doelman and Haanstra (1984) verified significant decreases in $\mathrm{CO}_{2}$ evolution from such soils, while Bardgett and Saggar (1994) and Welp (1999), on the other hand, recorded high increases. Such phenomenon is linked with varied interferences.

The current study aimed at evaluating the delayed effect of a natural modified clay mineral fortified with certain remediation amendments on a soil irrigated with low quality water $\mathrm{s}$ for extended periods through their microbial activities represented by $\mathrm{CO}_{2}$ evolution.

\section{MATERIAL AND METHODS}

\subsection{STUDY SITE}

A surface soil sample $(0-30 \mathrm{~cm})$, irrigated with low quality water for 40 years was collected from El-Rahawy farm, Giza governorate. The chemical characterization of the soil showed it to have $\mathrm{pH}, 6.83$; EC, $0.2 \mathrm{dSm}^{-1}$; OM (organic matter), $0.2 \%$; clay content, $4.4 \%$ and with a sandy texture. Determined inorganic pollutants in the tested soil were $18 \mathrm{ppm} \mathrm{Ni} 35.65 \mathrm{ppm} \mathrm{Cu} ; 400.6 \mathrm{ppm} \mathrm{Zn}$; $596 \mathrm{ppm} \mathrm{Fe} ; 45.19 \mathrm{Mn}$ 57.7ppm Pb and the $\mathrm{Zn}$ equivalent parameter was 633.9.

\subsection{EXPERIMENTAL DESIGN}

In a completely randomized pot experiment with four replicates, single and combined mixtures of varied remediation inorganic amendments were trailed to retain PTE's from a contaminated soil ecosystem irrigated with low quality water for extended periods. The soil was treated with either $2 \%$ probentonite (T1), $2 \%$ kaolinite (T2), $1 \%$ probentonite $+1 \%$ Kaolinite (T3), $1 \%$ probentonite $+1 \%$ rock phosphate (RP) (T4), $1 \%$ kaolinite + $1 \%$ RP (T5), $1 \%$ Bentonite $+0.5 \%$ kaolinite $+0.5 \%$ RP (T6), $2 \%$ iron oxide (T7) and $1 \%$ iron oxide $+1 \%$ RP (T8). Treated and untreated control soils were moistened to $60 \%$ of the soil water holding capacity and incubated for 60 days at $25^{\circ} \mathrm{C}$. At the end of incubation time $(60$ days), a kinetic study was carried out on treated and untreated soil ecosystems followed by a distribution study of inorganic pollutants studied.

\subsection{INORGANIC POLLUTANTS INSTRUMENTA- TION AND ANALYSIS}

A Perkin-Elmer flame atomic absorption spectrometer (FAAS) and HACH DR890 colorimeter was used in inorganic pollutants instrumentation and analyses. Atomic absorption measurements were carried out using air: acetylene flame while $\mathrm{HACH}$ colorimeter measurement with the provided test kits. The operating parameters for working elements were set of as recommended by the manufacturer.

\subsection{POTENTIAL TOXIC ELEMENTS DISTRIBU- TION ANALYSIS}

Inorganic pollutants were fractionated to water soluble, exchangeable, (readily available form RA), 
carbonate-bound, Fe-Mn oxides-bound ad organicbound which was considered to be the residual fraction (Zaghloul, 2002). The soil quality criterion index ( $\mathrm{Zn}$ equivalent model) was numerically expressed for the levels of PTE's toxicity as described by Saber et al. (2012). A quality criterion index for zinc equivalent over 250 units indicated a risky situation. Kinetic studies were carried out using the Electrical Stirred Flow Unit (ESFU) method.

\section{$2.5 \mathrm{CO}_{2}$ EFFLUX AND KINETIC EQUATION}

$\mathrm{CO}_{2}$ evolved during the incubation was trapped in $1 \mathrm{M} \mathrm{NaOH}$, and the excess $\mathrm{NaOH}$ was titrated with 0.1 $\mathrm{M} \mathrm{HCl}$ after the addition of $\mathrm{BaCl}_{2}$. Total $\mathrm{CO}_{2}$ mineralized was calculated as cumulative $\mathrm{CO}_{2}$ evolution (Leifeld et al., 2002). The specific respiration activity $\left(\mathrm{qCO}_{2}\right)$ was expressed as the production of $\mathrm{CO}_{2}-\mathrm{C}$ per unit biomass $\mathrm{C}$ and time.

Kinetic equations: The following four kinetic equations representing both empirical and theoretical equations were used to test the conformity of the $\mathrm{CO}_{2}$ release data to each of them.

\subsubsection{First order equation}

$$
\log \left(q_{j}-q_{t}\right)=\log q_{0}-k_{1} t
$$

where:

$q_{j}=$ the maximum amount of $\mathrm{CO}_{2}$ release

$q_{0}=$ the initial amount of $\mathrm{CO}_{2}$ at the time of added the resin.

$q_{t}=$ the amount of $\mathrm{CO}_{2}$ release at time $\mathrm{t}$.

$t=$ time in minute

$k_{1}=$ the rate constant of reaction $\mathrm{n}$ in $\sec ^{-1}$

\subsubsection{Elovich équation}

$q=(1 / b) \ln (a b)+(1 / b) \ln t$

where:

$q=$ amount of $\mathrm{CO}_{2}$ desorbed at time $\mathrm{t}$

$a=$ constant in ppm $\mathrm{CO}_{2} \mathrm{~min}^{-1}$

$b=$ constant in $\left(\mathrm{ppm} \mathrm{CO}_{2}\right)^{-1}$

$t=$ time in minute

\subsubsection{Modified Freundlich equation}

$$
\mathrm{q}=\mathrm{k}_{\mathrm{d}} \mathrm{t}^{\mathrm{bl}}
$$

where:

$q=$ amount of $\mathrm{CO}_{2}$ desorbed in time $\mathrm{t}$ $\min ^{-1}$

$k_{d}=$ desorption rate coefficient in $\mathrm{mg} \mathrm{CO}_{2} \mathrm{~kg}^{-1}$ soil

$b^{\backslash}=$ constant in $\mathrm{mg} \mathrm{CO}_{2} \mathrm{~kg}^{-1}$ soil

\subsection{SOIL MICROBIAL BIOMASS}

Soil microbial biomas was measured by the fumigation-extraction method after 24, 72, 96, 168, 240 and 336 hours. Three replicates of each treatment were fumigated with ethanol-free chloroform for $24 \mathrm{~h}$ at $25^{\circ} \mathrm{C}$. The soil samples were then extracted with $0.5 \mathrm{M} \mathrm{K}_{2} \mathrm{SO}_{4}$ for 30 $\mathrm{min}$. Three replicates of non-fumigated soil samples were extracted similarly. The extracted PTE's were determined by dichromate oxidation at $100{ }^{\circ} \mathrm{C}(2 \mathrm{ml}$ of extract, 1.5 $\mathrm{ml}$ of $15 \mathrm{M} \mathrm{H}_{2} \mathrm{SO}_{4}$ and $\otimes 1.5 \mathrm{ml}$ of saturated aqueous solution of $\mathrm{K}_{2} \mathrm{Cr}_{2} \mathrm{O}_{7}$ ). The residual $\mathrm{K}_{2} \mathrm{Cr}_{2} \mathrm{O}_{7}$ was determined by photometrical at $565 \mathrm{~nm}$ (Kuzyakov, 1997). The calibration of the extracted C (carbon) measurements was carried using glucose. $\mathrm{CO}_{2}$ evolved during incubation was trapped in $1 \mathrm{M} \mathrm{NaOH}$, and the excess $\mathrm{NaOH}$ was titrated with $0.1 \mathrm{M} \mathrm{HCl}$ after addition of $\mathrm{BaCl}_{2}$ (USEPA. 2001). Total mineralized $C$ was calculated as cumulative $\mathrm{CO}_{2}$ evolution (Leifeld et al., 2002). The specific respiration activity $\left(\mathrm{qCO}_{2}\right)$ was expressed as the production of $\mathrm{CO}_{2}-\mathrm{C}$ per unit biomass $\mathrm{C}$ and time (Anvar and Oliver Dilly, 2002).

\subsection{STATISTICAL ANALYSIS}

Multiple linear regressions, discriminant analysis and the fitting of curves to the data were performed using separate two-way ANOVAs. The data of biomass inorganic pollutants and soil organic $\mathrm{C}$ were analyzed by discriminate analysis. Statistical analyses aimed to examine the succession of the applied remediation amendments in returning the studied contaminated soil ecosystem to its normal settings. SAS software was used to evaluate the kinetic models that describe $\mathrm{CO}_{2}$ efflux under the action of the used different remediation amendments.

\section{RESULTS AND DISCUSSION}

\subsection{KINETICS OF $\mathrm{CO}_{2}$ EFFLUX IN BIO-REMEDI- ATED SOIL ECOSYSTEM}

Results drawn in Figure 1 demonstrate the kinetics of $\mathrm{CO}_{2}$ efflux from both contaminated and bio-remediated soil ecosystems. All trailed remediation amendments 
led to marked decreases in the rate of $\mathrm{CO}_{2}$ efflux compared to control contaminated soil ecosystem. In control contaminated soil ecosystem, maximum $\mathrm{CO}_{2}$ efflux reached $14.11 \mathrm{mg} \mathrm{kg}^{-1}$ soil; while being $10.45 \mathrm{mg} \mathrm{kg}^{-1}$ soil in T3 (soil fortified with a mixture of bentonite + kaolinite) and decreased to 8.2 in T8 (iron oxide + RP). Other trailed remediation amendments, thereafter decreased $\mathrm{CO}_{2}$ efflux with values higher than in abovementioned treatments was recorded.

Chander and Brookes (1993), stated that when Zn and $\mathrm{Cu}$ are present together in the soil ecosystem the increase in $\mathrm{Zn}$ and $\mathrm{Cu}$ bioavailability above 123 or $3.0 \mathrm{ppm}$ causes marked decreases in the intensity of soil microbial biomass.

Results given in Figure 2 show that the impacts of the trailed remediation amendments in minimizing the hazards of PTE's varied according to their type. Modified bentonite, iron oxide, rock phosphate as well as the mixture of these remediation amendments decreased significantly the evolution of $\mathrm{CO}_{2}$ or restored the soil ecosystem to its normal conditions. Of all treatments T8, T3 and $\mathrm{T} 7$ were the best that condensed normal conditions, in some cases; however, certain remediation amendments increased the $\mathrm{CO}_{2}$ to a non-significant level compared to control especially when fortified with kaolinite (T5) even in the absence of RP.

\subsection{RATE CONSTANTS OF BEST FITTED MODELS DESCRIBE $\mathrm{CO}_{2}$ EFFLUX AS AFFECTED BY REMEDIATION AMENDMENTS APPLIED TO SOIL ECOSYSTEM}

Kinetic approach was used to evaluate the effectiveness of the trailed remediation amendments on $\mathrm{CO}_{2}$ efflux that express the biomass activity as well as the depressing action of PTE's associated with the trailed remediation amendments.

As given in Tables 1-3, the rate constants of $\mathrm{CO}_{2}$ efflux from the soil irrigated with low quality water for extended periods, as an indicator for microbial activity, varied according to type of the trailed remediation amendment. For MFE, the best fitted model, the application of kaolinite and RP (T5) decrease $\mathrm{CO}_{2}$ efflux to $0.71 \mathrm{mg} \mathrm{g}^{-1}$ soil, in control the value was $0.77 \mathrm{mg} \mathrm{g}^{-1} \mathrm{~min}$ ${ }^{1}$. Fortification of the soil ecosystem irrigated with low quality water with iron oxide also decreased $\mathrm{CO}_{2}$ efflux to $0.68 \mathrm{mg} \mathrm{g}^{-1} \mathrm{~min}^{-1}$, and hence might be used to cure such contaminated soil ecosystem. Also, using bentonite in $\mathrm{T} 1$ decreased the $\mathrm{CO}_{2}$ flux to $0.68 \mathrm{mg} \mathrm{g}^{-1} \mathrm{~min}^{-1}$. All other trailed remediation amendments significantly decreased $\mathrm{CO}_{2}$ efflux compared to control. The negative values recorded for the capacity factor in the same model means returning the soil ecosystem to optimum conditions for microbial activity.

\subsection{MICROBIAL BIOMASS IN PTE'S CONTAMI- NATED AND BIO-REMEDIATED SOIL ECO- SYSTEMS}

Results given in Table 4 show the amount of contaminants absorbed by the microbial biomass in the soil ecosystem. In control microorganism's absorbed significant amounts of inorganic pollutants reached $0.46 \mathrm{ppm}$ $\mathrm{Zn}, 0.03 \mathrm{Cu}$ and $0.10 \mathrm{Ni}$. The existence and uptake of all inorganic pollutants directly led to an increase in the microbial activity in the soil ecosystem. For example, in $\mathrm{T} 1$ only Ni was absorbed by microorganisms, meanwhile other studied inorganic pollutants did not presented in side microorganisms.

The same trend was re-exhibited in T3, T5 and T7 treatments. Bentonite + kaolinite + rock phosphate (RP) treatment (T6) and iron oxide + RP treatment (T8) also increased the microbial activity through increasing $\mathrm{CO}_{2}$ efflux of rate constants of Elovich kinetic model (Table 3). Results in the same table point to that bentonite as remediation amendment decreased inorganic pollutants uptake at different degrees with some exception observed in case of $\mathrm{Ni}$.

Although the application of oxides as remediation amendment was extensively mentioned in literature, the application of iron oxides in this study enhanced $\mathrm{Zn}$ and $\mathrm{Ni}$ by microorganisms found in the soil ecosystem. It is worth to state that $\mathrm{Cu}$ was the only PTE that was depressed by the trailed remediation amendments though the increasing of non fumigated values compared to fumigated ones.

\subsection{CONTRIBUTION OF TRAILED REMEDIATION AMENDMENTS IN SOIL ECOSYSTEMS ON MINIMIZING THE HAZARDS OF PTE'S}

The effect of trailed remediation amendments on minimizing the hazards of $\mathrm{Ni}, \mathrm{Cu}$ and $\mathrm{Zn}$ is drawn in Figure 3 that show all trailed treatments significantly decreased the available forms of the studied inorganic pollutants compared to control. The comparison between the different treatments indicated that bentonite significantly decreased the available form of PTE's. For instances, the application of modified bentonite to soil (T4) led to a decrease reaching $34 \%$ of available of $\mathrm{Cu}$, $79 \%$ of available $\mathrm{Zn}$ and $77 \%$ of available Ni.

The mixture of bentonite and kaolinite decreased $68 \%$ of available $\mathrm{Cu}, 66 \%$ of available $\mathrm{Zn}$ and $59 \%$ of 


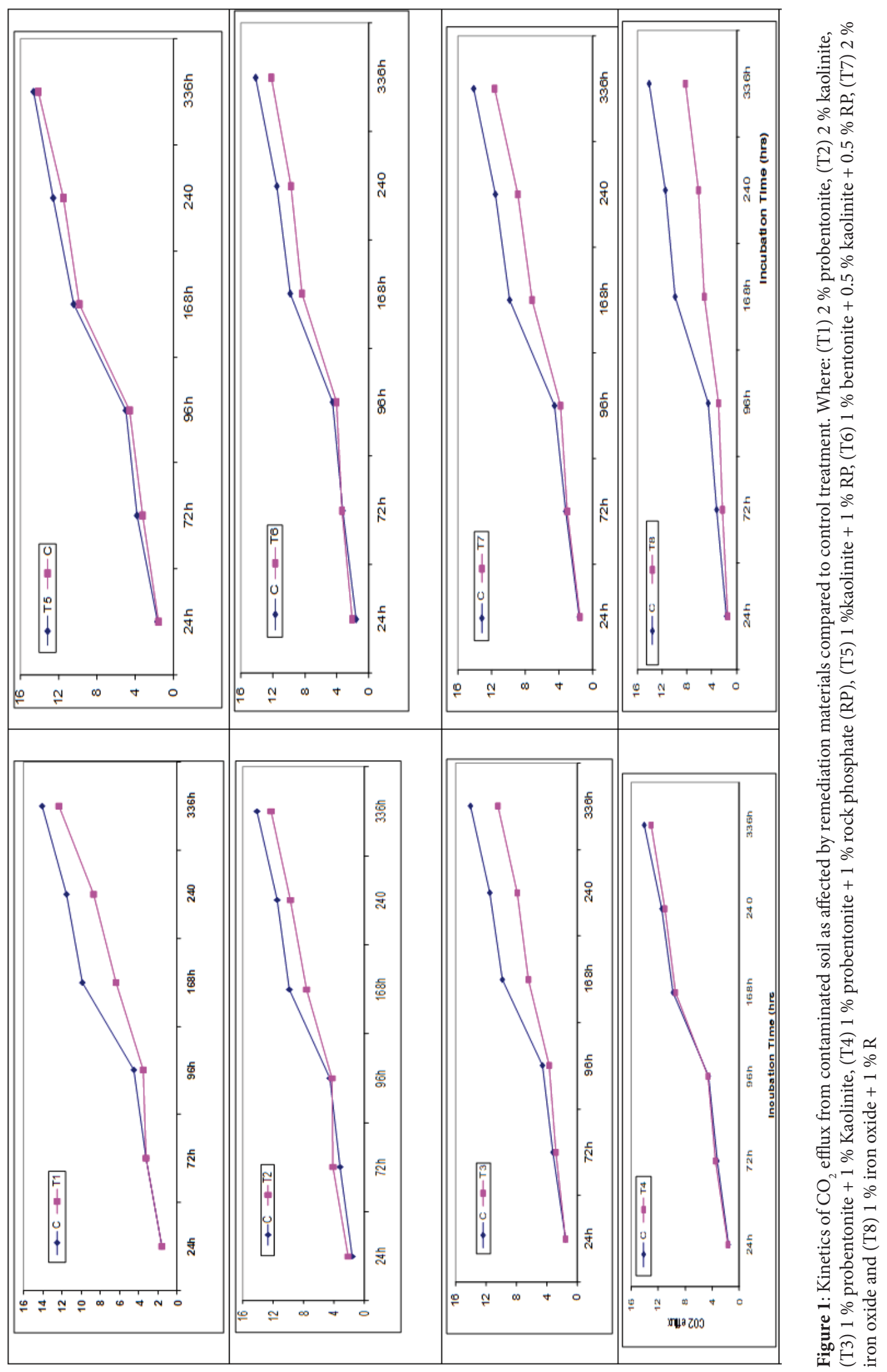




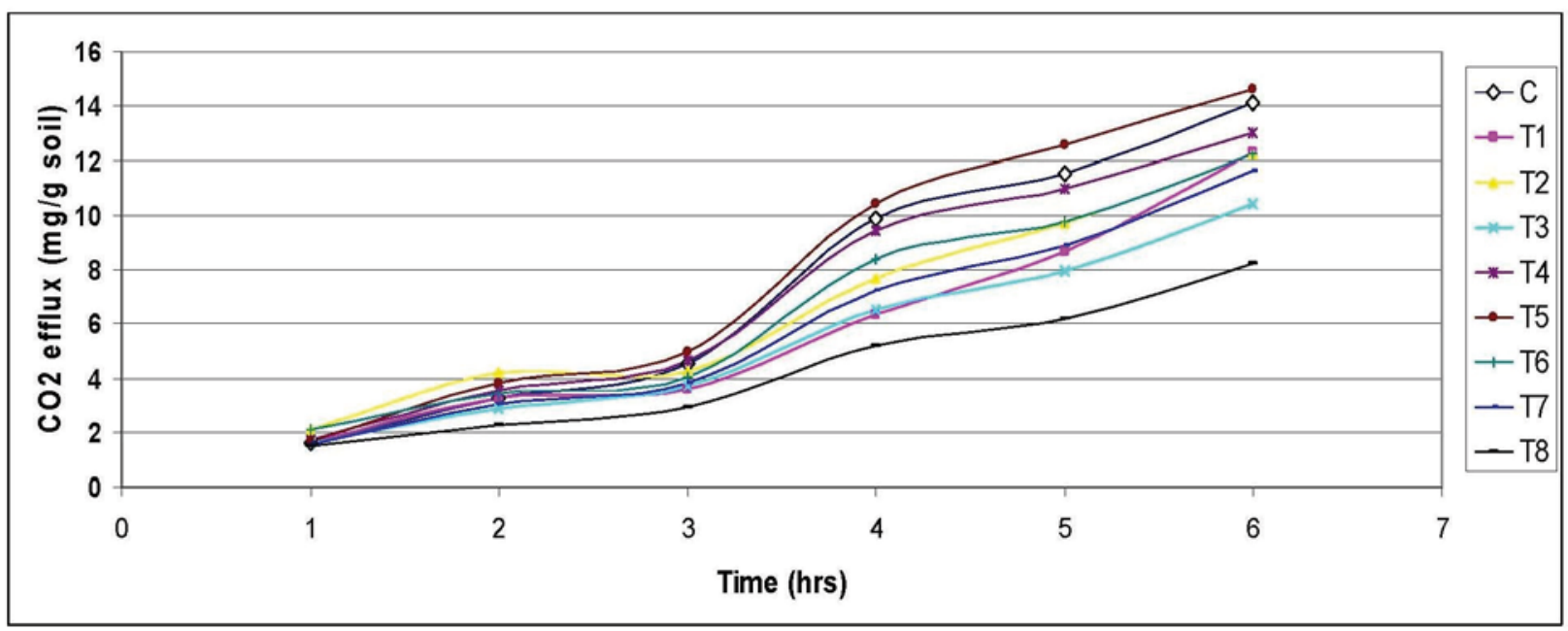

Figure 2: Map showing the experimental plots and location of the experiment at the Institute of Agricultural Research and Training in Ibadan, Oyo state, Nigeria. (T1) $2 \%$ probentonite, (T2) $2 \%$ kaolinite, (T3) $1 \%$ probentonite $+1 \%$ kaolinite, (T4) $1 \%$ probentonite $+1 \%$ rock phosphate (RP), (T5) $1 \%$ kaolinite $+1 \%$ RP, (T6) $1 \%$ bentonite $+0.5 \%$ kaolinite + $0.5 \%$ RP, (T7) $2 \%$ iron oxide and (T8) $1 \%$ iron oxide $+1 \%$ RP

Table 1: Rate constants of $1^{\text {st }}$ order model describe $\mathrm{CO}_{2}$ efflux from contaminated soil as affected by remediation treatments

\begin{tabular}{lllll}
\hline Treatments & $\mathrm{a}^{\star} 10^{\wedge} 4$ & $b$ & $\mathrm{R}^{2}$ & $\mathrm{SE}$ \\
\hline cont & -5.51 & 11.58 & $0.99^{\star *}$ & 0.21 \\
T1 & -5.96 & 10.95 & $0.99^{\star *}$ & 0.40 \\
T2 & -5.12 & 9.62 & $0.99^{\star *}$ & 0.35 \\
T3 & -7.71 & 12.53 & $0.97^{\star *}$ & 0.81 \\
T4 & -8.95 & 14.36 & $0.99^{\star *}$ & 0.80 \\
T5 & -6.43 & 11.33 & $0.96^{\star *}$ & 0.73 \\
T6 & -5.94 & 11.00 & $0.99^{\star *}$ & 0.43 \\
T7 & -3.88 & 7.40 & $0.99^{\star *}$ & 0.36 \\
T8 & -5.51 & 11.58 & $0.98^{* *}$ & 0.21 \\
\hline
\end{tabular}

available $\mathrm{Ni}$, this trend perhaps represents the selectivity of used clay minerals in retain PTE's. Results pointed to that increasing of $\mathrm{Cu}$ and $\mathrm{Zn}$ was retained by kaolinite over bentonite, meanwhile a reverse trend was observed in Ni. The modification of kaolinite with RP increased the retention of $\mathrm{Ni}$ by $64 \%$ in the soil ecosystem; meanwhile it did not exceed $18 \%$ under sole kaolinite application.

The same treatment, however, did not influence the retention level of $\mathrm{Cu}$ and $\mathrm{Zn}$ in the soil ecosystem. In contrast, fortification of the soil ecosystem with sole iron oxide decreased the retention of inorganic pollutants to 65, 72 and $45 \%$ of $\mathrm{Cu} \mathrm{Zn}$ and Ni respectively, while the mixture of PR with iron oxide decreased these values re-
Table 2: Rate constants of MFE describe $\mathrm{CO}_{2}$ efflux from contaminated soil as affected by remediation treatments

\begin{tabular}{lllll}
\hline Treatments & $\mathrm{a}$ & $\mathrm{b}$ & $\mathrm{R}^{2}$ & $\mathrm{SE}$ \\
\hline cont & 0.77 & 2.29 & $0.99^{\star *}$ & 0.05 \\
T1 & 0.68 & -1.86 & $0.99^{\star *}$ & 0.04 \\
T2 & 0.74 & -2.17 & $0.99^{\star *}$ & 0.04 \\
T3 & 0.72 & -2.39 & $0.99^{\star *}$ & 0.05 \\
T4 & 0.68 & -2.56 & $0.99^{\star *}$ & 0.05 \\
T5 & 0.71 & -1.99 & $0.98^{\star *}$ & 0.07 \\
T6 & 0.75 & -2.29 & $0.99^{\star *}$ & 0.05 \\
T7 & 0.68 & -1.86 & $0.99^{* *}$ & 0.04 \\
T8 & 0.74 & -2.17 & $0.99^{* *}$ & 0.04 \\
\hline
\end{tabular}

spectively to 50,30 and $36 \%$ of total form in soils. Results drawn in the same figure indicated that the mixture of all treatment (T6) did not exhibit the predicted trend since the decreasing orders of Inorganic pollutants did not exceed 34, 62 and $55 \%$ of total $\mathrm{Cu}, \mathrm{Zn}$ and $\mathrm{Ni}$ compared to control in order to be a valued treatment but not the best

\subsection{DISTRIBUTION OF THE STUDIED PTE'S IN REMEDIATED SOIL ECOSYSTEM}

Results drawn in Figure 4 exhibit the distribution of $\mathrm{Ni}, \mathrm{Cu}$ and $\mathrm{Zn}$ in soil ecosystem irrigated with low qual- 
ity water for long periods as affected by the trailed remediation amendments applied to minimize the hazards of PTE's and to optimize microbial activities through remediation of soil ecosystem. Generally, as shown in the Figure 4, trailing the different remediation amendments decreased the readily available form and increased the residual one with rates varied according to amendment used. Three main categories of the trailed remediation amendments are distinguished, the $1^{\text {st }}$ category included the best ones, i.e., pro-bentonite (T4), pro-kaolinite (T5) and iron oxide (T7), which minimized the readily available form to zero in $\mathrm{Ni}$ and from 98 to $100 \%$ for $\mathrm{Cu}$ and

Table 3: Rate constants of Elovich equation describe $\mathrm{CO}_{2}$ efflux from contaminated soil as affected by remediation treatments

\begin{tabular}{lllll}
\hline Treatments & $\mathrm{a}$ & $b$ & $\mathrm{R} 2$ & $\mathrm{SE}$ \\
\hline cont & 3.85 & -28.08 & $0.92^{\star \star}$ & 1.77 \\
T1 & 3.82 & -27.09 & $0.95^{\star \star}$ & 1.40 \\
T2 & 3.34 & -24.00 & $0.94^{\star \star}$ & 1.25 \\
T3 & 4.57 & -33.12 & $0.95^{\star *}$ & 1.54 \\
T4 & 5.24 & -38.31 & $0.95^{\star \star}$ & 1.76 \\
T5 & 3.97 & -28.46 & $0.94^{\star \star}$ & 1.59 \\
T6 & 3.82 & -27.77 & $0.94^{\star \star}$ & 1.44 \\
T7 & 2.54 & -18.10 & $0.93^{\star \star}$ & 1.04 \\
T8 & 3.85 & -28.08 & $0.92^{\star \star}$ & 1.77 \\
\hline
\end{tabular}

$\mathrm{Zn}$, i.e., increased the residual form in these treatments. The $2^{\text {nd }}$ category included the remediation amendments able to minimize the available form of one of the tested inorganic pollutants to zero such as T3 (the mixture between bentonite and kaolinite) in case of $\mathrm{Cu}$. The $3^{\text {rd }}$ category included the rest of treatments that significantly minimized inorganic pollutants at different rates according to the studied inorganic pollutants.

It should be mention that all applied remediation amendments are locally available in Egypt and are considered with economic low coast. Various methods such as hydrometallurgical technologies, ion exchange, electro dialysis, reverse osmosis, precipitation and adsorption had been trailed to remove inorganic pollutants from aqueous solution phase in aquatic ecosystems (La Grega et al., 1994). It is well known that the reduction in the readily available forms of inorganic pollutants' in contaminated soil ecosystems is a commonly technique used to reduce the negative impacts of inorganic pollutants on environment and improve the quality of contaminated soil ecosystems (Zaghloul, 2006). It is well known that clay minerals interact with almost all soil contaminants (Prost and Yaron, 2001). The adsorption of Ni, Cd, Zn, and $\mathrm{Pb}$ by the clay mineral montmorillonite was reported by Schulthess and Huang (1990). Sorption technique is one of the most efficient methods of cleaning the environment from Inorganic pollutants.

In this study microbial activity through $\mathrm{CO}_{2}$ efflux was used as an indicator to evaluate the effectiveness of eight remediation amendments in minimizing the hazards of PTE's in soil ecosystem. Bentonite is a well-known as one of the most effective remediation amendments

Table 4: Microbial biomass for $\mathrm{Ni}, \mathrm{Cu}$ and $\mathrm{Zn}$ in both contaminated and remediated soils

\begin{tabular}{|c|c|c|c|c|c|c|}
\hline & $\mathrm{NF}$ & Fum. & NF & Fum & NF & Fum \\
\hline Treatments & $\mathrm{Zn}$ & $\mathrm{Zn}$ & $\mathrm{Cu}$ & $\mathrm{Cu}$ & $\mathrm{Ni}$ & $\mathrm{Ni}$ \\
\hline & \multicolumn{6}{|c|}{ ppm } \\
\hline Control & 2.65 & 3.11 & 1.24 & 1.27 & 1.80 & 10.9 \\
\hline $\mathrm{T} 1$ & 0.86 & 0.42 & 1.69 & 1.34 & 1.89 & 2.36 \\
\hline $\mathrm{T} 2$ & 2.00 & 0.99 & 0.82 & 0.71 & 2.3 & 1.61 \\
\hline T3 & 0.54 & 0.31 & 0.58 & 0.41 & 1.88 & 2.23 \\
\hline $\mathrm{T} 4$ & 6.53 & 4.85 & 1.21 & 1.08 & 2.04 & 2.22 \\
\hline T5 & 3.13 & 2.71 & 0.85 & 0.77 & 1.44 & 2.02 \\
\hline T6 & 0.3 & 0.44 & 0.96 & 0.52 & 1.66 & 2.36 \\
\hline $\mathrm{T} 7$ & 1.21 & 0.78 & 0.89 & 0.89 & 1.75 & 2.05 \\
\hline T8 & 3.29 & 4.39 & 0.88 & 0.78 & 1.89 & 2.71 \\
\hline
\end{tabular}

NF: non-fumigated, Fum: Fumigated 

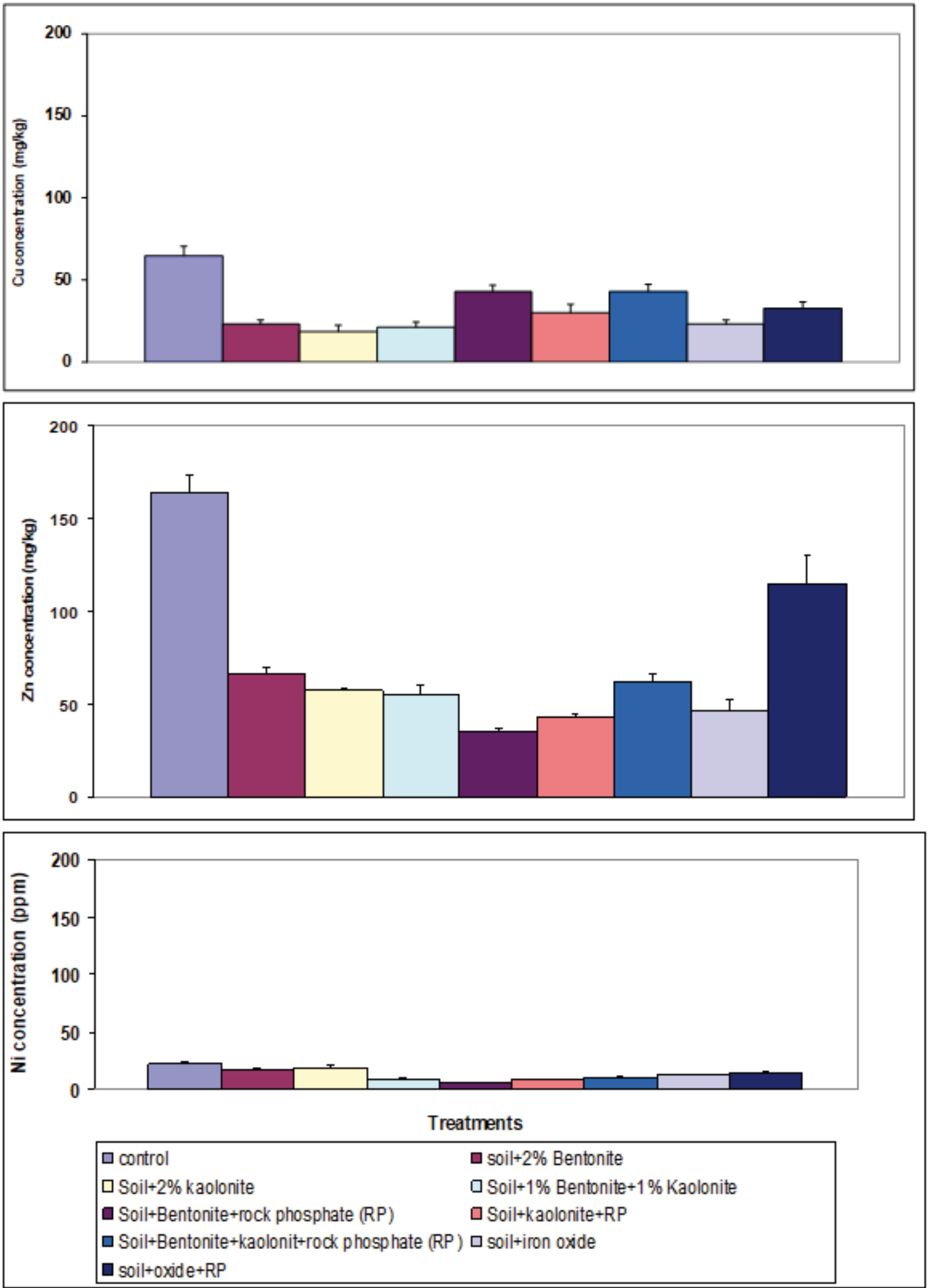

Figure 3: Potential toxic elements availability in contaminated as affected by remediation materials compared to control treatments

8 | Acta agriculturae Slovenica, 117/4 - 2021 


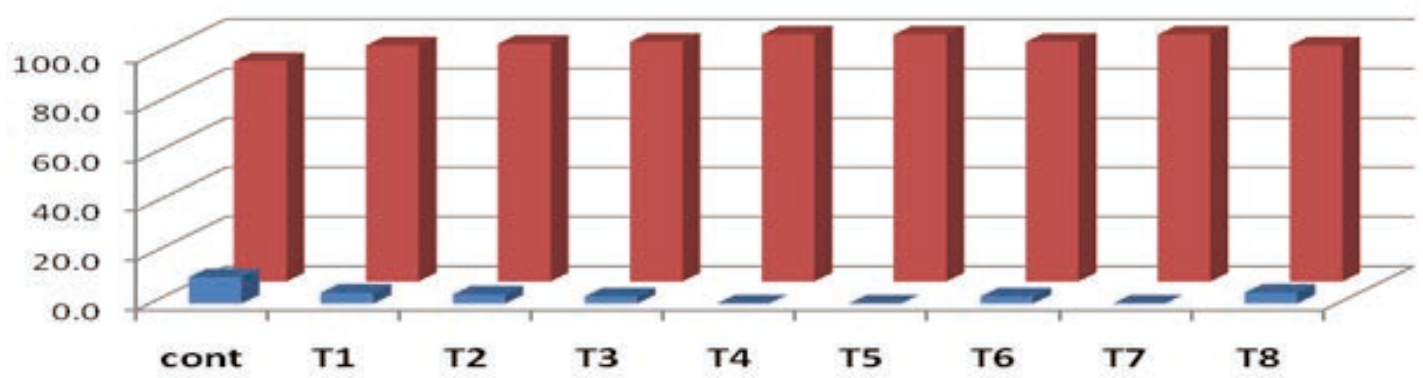

Cu
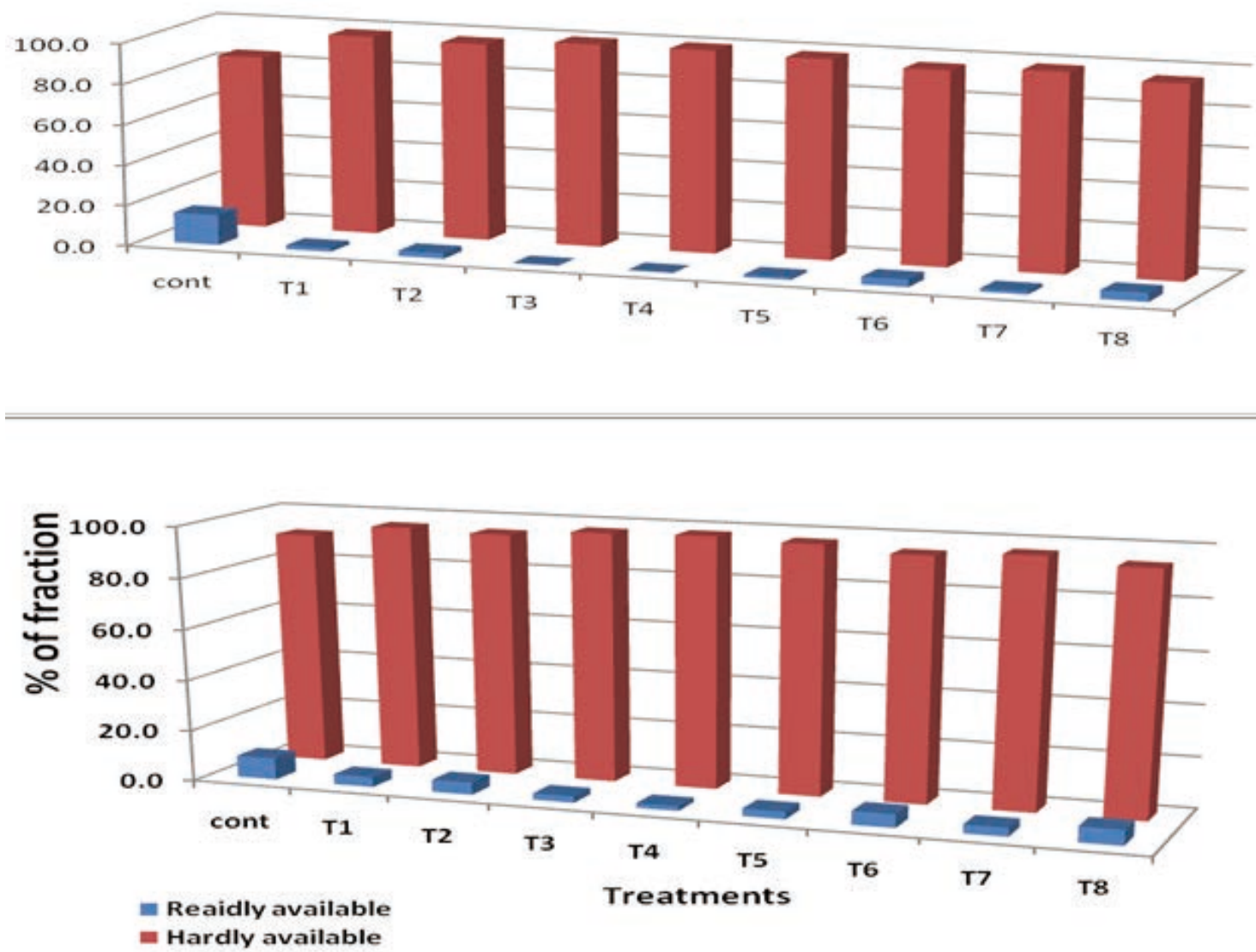

Figure 4: Distribution of PTE's in the studied low quality water soils as affcted by certain remediative amendments. (T1) $2 \%$ probentonite, (T2) $2 \%$ kaolinite, (T3) $1 \%$ probentonite $+1 \%$ kaolinite, (T4) $1 \%$ probentonite $+1 \%$ rock phosphate (RP), (T5) $1 \%$ kaolinite $+1 \%$ RP, (T6) $1 \%$ bentonite $+0.5 \%$ kaolinite $+0.5 \%$ RP, (T7) $2 \%$ iron oxide and (T8) $1 \%$ iron oxide $+1 \%$ RP 
used in curing soil ecosystems contaminated with certain inorganic pollutants such as $\mathrm{Ni}, \mathrm{Cu}, \mathrm{Zn}$ and others (Andini et al., 2006). In addition, bentonite has been shown to improve the overall soil quality (Phillips, 1998). Application of bentonite to soils irrigated with low quality water s significantly retained PTE's in different mechanisms such as sorption and ion exchange mechanisms. The optimum conditions of soil ecosystem to decrease the availability of PTE's might obviously monitored through the microbial activity of decreasing the $\mathrm{CO}_{2}$ efflux.

Although both bentonite and pro-bentonite showed priority in minimizing the hazards of PTE's in the studied soil ecosystem, yet, kaolinite exhibited the least exchangeability among bentonite clay mineral group, as several studies confirmed the potential of natural kaolinite in metal ion adsorption from solution. O'Day et al. (1994) mentioned that $\mathrm{CO}_{2}$ is always binding to kaolinite as co-complexes at both inner and outer sphere complexes using X-ray absorption spectroscopy (XAS). Boron adsorption on kaolinite was studied by Singh and Mattigod (1992) using phenomenological equations and surface complication reactions. Samaneh and Jalali (2016) evidenced strong preference for the ion exchanged form of kaolinite for $\mathrm{Cu}$ ions. Exchange capacity of both cation as well as anion of kaolinite and their relation with homo ionic counterparts with $\mathrm{Na}+$ was critically examined by Ferris and Jepson (1975).

Results indicated that the succession of more than one model in describing the kinetic results having high $\mathrm{R}^{2}$ values ranged between $96-99^{* *}$ in used models. This means that the different mechanisms that took place in the sorption of studied PTE's by the trailed remediation amendments improved $\mathrm{CO}_{2}$ efflux by decreasing the available form of PTE's.

The outer groups were situated along the unshared plane of the alumina hydroxyl sheet, while the inner groups were located along the plane that is shared with and borders on the silica oxide sheet. The movement of the inner hydroxyl plane is restricted as a result of chemical bonding between the silica and alumina sheets. The pro- clay mineral treatment in all cases directly increased the retention of PTE's, this trend decreased the microbial biomass of these treatment. This result might be due to the mode of phosphate reaction with all PTE's in having complex compounds (Ma and Harris, 1997). Worth to mention that iron oxide exhibited the same trend when $\mathrm{RP}$ was applied to the soil ecosystem.

Sorption and immobilization of inorganic pollutants in soil ecosystem is an effective detoxification process and thus it is an essential part of the buffering capacity of the soil ecosystem (Welp 1999).

Immobilization of inorganic pollutants caused an increase in basal respiration rate, litter decomposition and microbial activity. There are several methods for immobilization of inorganic pollutants in soil, through either adding natural and synthetic chemical additives such as alkaline materials, phosphate minerals, iron and manganese oxides, alumino-silicates or coal fly ashes (Mench et al., 1998). Clay minerals are among the major materials that interact with almost all soil contaminants (Prost and Yaron, 2001). The adsorption of Ni, Cd, Zn, and $\mathrm{Pb}$ by montmorillonite was reported by Schulthess and Huang (1990). Immobilization of inorganic pollutants by natural zeolite (clinoptilolite) and six synthetic zeolites was studied by Oste et al. (2002), who found that the synthetic zeolites had an effect on immobilization of $\mathrm{Cd}$ and $\mathrm{Zn}$. The improvement of the quality of the microbe's media through is mainly due to ameliorative action of PTE's in soil ecosystem irrigated with low quality water for extended periods.

\section{CONCLUSIONS AND RECOMMENDA- TIONS}

The application of microbial activity through $\mathrm{CO} 2$ flux in evaluation soil remediation technology(ies) can be a viable and innovative best way. In this work, the use of some clay minerals, crude or modified with some microbes, significantly reduced the content of harmful heavy metals in a soil ecosystem irrigated with low-quality water for long periods. The treatments used led to a significant decrease in the available forms of the studied heavy elements in parallel with the increase in the residual unavailable forms of pollutants. According to the obtained results, heavy metal ions showed a tendency to accumulate on clay minerals, which shows the importance of this method of treatment and suitability for improving soil quality by restoring appropriate ecosystem conditions and flourishing microbial activity. This method is also characterized by low costs and an economical way that encourage the farmers to use it for having safe food. It is worth noting the importance and necessity of using this technique more in other studies with other polluted metals that did not fall within the scope of this research.

\section{ABBREVIATIONS}

NRC: National Research Centre

PR: Rock phosphate

CO2: Carbon dioxide

$\mathrm{Cu}$ : copper

Ni: Nickel

Zn: Zinc

PR: Rock phosphate 
$\mathrm{K}_{2} \mathrm{Cr}_{2} \mathrm{O}_{7}$ : Potassium dichromate

ANOVA: Analysis of variance

R2: Coefficient of determination

SE: Standard Error

NF: Non-fumigated

Fum: Fumigated

\section{ACKNOWLEDGMENT}

The authors would like to express their appreciation and gratitude to the Science, Technology \& Innovation Funding authority (STDF) for financing the present work through the project number 41523 contracted with the National Research Center and extended till present.

\section{REFERENCES}

Andini S., Cioffi F., Montagnaro F., and Santoro L. (2006). Simultaneous adsorption of chlorophenol and heavy metal ions on organophilic bentonite. Applied Clay Science, 31, 126-133. https://doi.org/10.1016/j.clay.2005.09.004

Anvar S.H. and Oliver M. (2002). Soil microbial eco-physiology as affected by short-term variations in environmental conditions. Soil Biology and Biochemistry, 34, 1283-1290. https://doi.org/10.1016/S0038-0717(02)00071-8

Bardgett RD. and Saggar S. (1994). Effects of heavy metal contamination on the short-term decomposition of labelled $14 \mathrm{C}$ glucose in a pasture soil. Soil Biology and Biochemistry, 26, 727-733. https://doi.org/10.1016/0038-0717(94)902658

Chander K and Brookes P (1993). Residual effects of zinc, copper and nickel in low quality water sludge on microbial biomass in a sandy loam. Soil Biology and Biochemistry, 25, 1231-1239. https://doi.org/10.1016/0038-0717(93)90219-2

Doaa Ali, Omaima Sharaf, Mohamed Saber, Essam Hoballah, Mohamed Khaled Ibrahim, Einas El- Shatoury and Alaa Zaghloul (2020). Bioremediation of potential toxic elements in varied soil ecosystems (greenhouse scale). Plant Archives, 20, 9482-9490.

Doelman P. and Haanstra L. (1984). Short-term and long term effects of cadmium, chromium, copper, nickel, lead and zinc on soil microbial respiration in relation to abiotic soil factors. Plant and Soil 79: 317-327. https://doi.org/10.1007/ BF02184325

Ferris A. and Jepson W. (1975). The exchange capacities of kaolinite and the preparation of homoionic clays. Journal of Colloid Interface Science, 51, 245-259. https://doi. org/10.1016/0021-9797(75)90110-1

Khan M. and Scullion J. (1999). Microbial activity in grassland soil amended with low quality water sludge containing varying rates and combinations of $\mathrm{Cu}, \mathrm{Ni}, \mathrm{Zn}$. Biology and Fertility of Soils, 30, 202-209. https://doi.org/10.1007/ s003740050609

Kelly J. and Tate R. (1998). Effects of heavy metals contamination and remediation on soil microbial communi- ties in the vicinity of a zinc smelter. Journal of Environmental Quality, 27, 609-617. https://doi.org/10.2134/ jeq1998.00472425002700030019x

Kuzyakov Y. (1997). The role of amino acids and nucleic bases in turnover of nitrogen and carbon in soil humic fractions. European Journal of Soil Science, 48, 121-130. https://doi. org/10.1111/j.1365-2389.1997.tb00191.x

La Grega M., Buckingham P. and Evans, J. (1994). Hazardous Waste Management, McGraw Hill Publication.

Leifeld J., Siebert S. and Kogel-Knabner I. (2002). Biological activity and organic matter mineralization of soil amended with biowaste composts. Journal of Plant Nutrition and Soil Science, 165, 151-159. https://doi.org/10.1002/15222624(200204)165:2<151::AID-JPLN151>3.0.CO;2-T

Ma L., Tan F. and Harris W. (1997). Concentration and distribution of eleven metals in Florida soils, Journal of Environmental Quality, 26, 769-775. https://doi.org/10.2134/ jeq1997.00472425002600030025x

Mench M., Vangronsveld J., Lepp N. and Edwards R. (1998). Physio-chemical aspects and efficiency of trace element immobilisation by soil ammendments. In Metal contaminated soils: In situ inactivation and phytorestoration. SpringerVerlag and R.G. Edited by J. Vangronsveld and S.D. Cunningham. Landes Company, 151-182.

Mohamed Saber, Hussein, F. Abuouziena, Esam Hoballah, Fatma Abd-Elzaher, Azza Tyrkey and Alaa Zaghloul (2015). Risk assessment and mitigation measures for certain amendments used in bioremediation of low quality waterd soils. International Journal of ChemTech Research CODEN (USA): IJPRIF (ISSN: 0974-4304), 8(6), 423-440.

O’Day P., Parks G. and Brown G. (1994). Molecular structure and binding sites of $\mathrm{Co}^{2+}$ surface complexes on kaolinite from X-ray adsorption spectroscopy. Clays Clay Mineral, 42, 337-355. https://doi.org/10.1346/CCMN.1994.0420312

Oste L., Dolfing J., Ma W. and Lexmond T. (2001). Cd uptake by earthworms as related to the availability in the soil and the intestine. Environmental Toxicology and Chemistry, 20, 1785-1791. https://doi.org/10.1002/etc.5620200823

Phillips I.R. (1998) Phosphorus availability and sorption under alternating waterlogged and drying conditions. Communication of Soil Science and Plant Analysis, 29, 3045-3059. https://doi.org/10.1080/00103629809370175

Prost R. and Yaron B. (2001). Use of modified clays for controlling soil environmental quality. Soil Science,166, 880-895. https://doi.org/10.1097/00010694-200112000-00003

Saber M., Hobballa E., Soad El-Ashery and Zaghloul A. (2012). Decontamination of potential toxic elements in low quality water soils by inorganic amendments. Journal of Agricultural Science and Technology, A, 2, 1232-1244.

Samaneh T. and Mohsen J. (2016). Sorption, desorption, and speciation of $\mathrm{Cd}, \mathrm{Ni}$, and $\mathrm{Fe}$ by four calcareous soils as affected by $\mathrm{pH}$. Environmental Monitoring and Assessment, 6, 188-322. https://doi.org/10.1007/s10661-016-5313-4

SAS Institute (1985). SAS/STAT Guide for Personal Computers. 6th ed. SAS Ins., Cary, NC

Schulthess C.P. and Huang C.P. (1990). Adsorption of heavy metals by silicon and aluminum oxide surfaces on clay minerals. Soil Science Society American Journal, 54, 679-688. https://doi.org/10.2136/sssaj1990.03615995005400030008x 
Singh S.P. and Mattigod S.V. (1992) Modeling boron adsorption on kaolinite. Clays Clay Miner, 40, 192-205. https:// doi.org/10.1346/CCMN.1992.0400209

USEPA (2001). USEPA test methods. SW-846 manual. Available online at www.epa.gov/epaoswerlhazwaste/test/sw846.htm (verified11 Apr. 2003). USEPA, Washington, DC

Welp G. (1999). Inhibitory effects of the total and water-soluble concentrations of nine different metals on the dehydrogenase activity of a loess soil. Biology and Fertility of Soils, 30, 132-139. https://doi.org/10.1007/s003740050599

Yonebayashi K. and Hattori T. (1989). Chemical and biological studies on environmental humic acids: II. 1H-NMR and IR spectra of humic acids. Soil Science and Plant Nutrition, 35, 383-392. https://doi.org/10.1080/00380768.1989.10434771

Zaghloul A.M. (2002). Kinetics of potassium adsorption in some soils of Egypt using Electrical Stirred Flow unit (ESFU). Egyptian Journal of Soil Science, 42, 463-471.

Zaghloul A.M., Camilia El-Dewany and Yousef R.A. (2006). Distribution of $\mathrm{Pb}$ and $\mathrm{Zn}$ in some Egyptian contaminated soils as affected by time of exposure and source of pollutants. Journal of Applied Science Research. 2, 284-289. 